$\xi=$

\title{
Expert Examination of the Use of a Dependent Invention and a Dependent Utility Model Under the Law of the Russian Federation
}

\author{
Vladimir Evgenievich Kitaiskiy1, Evgeniy Nikolaevich Petrov2, Vera Vladimirovna Shvedova3 \\ 1-3Russian state academy of intellectual property \\ Miklukho-Maklaya St., 55a, Moscow, 117279, Russia
}

\begin{abstract}
The article deals with such objects of patent law as inventions and utility models, the use of which by patent holders in some cases is limited by the rights of other patent owners in accordance with the requirements of the Civil Code of the Russian Federation, as amended on March 12, 2014. Such inventions and utility models are called dependent. In fact, these are improvements to other inventions and utility models, to which the exclusive right applies. The patent owner of such a dependent object of patent law may legitimately use his invention or his utility model only upon obtaining the right to use another (main) object of patent law or at its alienation from the legal owner. For this, it is necessary to reveal the dependence of one's object of patent law on another (main) object. The article shows how it is possible to identify such dependence under the existing patent legislation of the Russian Federation.
\end{abstract}

Keywords: dependent invention, dependent utility model, patentee, exclusive right, legal and illegal use.

\section{Introduction}

The patent legislation of the Russian Federation includes a category of patent law objects - dependent inventions and dependent utility models [6].

For example, there are registered inventions and utility models, the use of which by patent holders is limited by the rights of other patent holders. This is due to the fact that such inventions or utility models are the improvements to other existing inventions or utility models or are the application of the invention as a product or a method for a different purpose. Such inventions and utility models are recognized as dependent inventions and dependent utility models from other inventions and other utility models [1, 7].

In accordance with patent law, the use of a dependent invention or a dependent utility model by the patent holder is not allowed without the consent of the patent holder of another invention or other utility model which is recognized as being used in the dependent invention/the dependent utility model [10].

In a case when using his object (product or method) a person also uses all the features of another object that is patented, the person must apply for a permission from the person who owns the prior patent for the other patent law object [8]. This is called the lack of patent noninfringement or the violation of the exclusive rights of third parties [9].

A dependent utility model, as well as a dependent invention, can be used to extend the lifetime of an engineering solution by obtaining a new dependent engineering solution, as described by E.B. Gavrilova [4].

The current edition of the Civil Code of the Russian Federation [2, 3] in Paragraph 4 of Article 1358 gives the regulation according to which an invention or a utility model is recognized as using another invention or useful model:
"An invention or utility model shall be deemed used in a product or process if the product contains or the process involves:

- each feature of the invention or utility model stated in an independent claim contained in the claims for the invention or utility model, or a feature equivalent thereto that has become known as such in this art prior to performance in respect to the respective invention,

- The use of all the characteristics listed in an independent claim of the claims contained in the patent of another invention or another utility model shall also be deemed used.

In the Civil Code of the Russian Federation (the Civil Code) such inventions and utility models are defined as "dependent" because they cannot be used without using another invention or other useful model. This is directly stated in Article 1358.1 of the Civil Code:

"An invention, utility model whose use in a product or method is impossible without using another invention, utility model protected by a patent and having an earlier priority shall be deemed a dependent invention, dependent utility model.

Seen as a dependent invention shall be, in particular, an invention protected in the form of application for a particular purpose of the product in which another invention protected by the patent and having an earlier priority is used.

An invention or utility model related to a product or method shall be also deemed dependent if the formula of such invention or such utility model differs from the formula of another patented invention or another patented utility model with an earlier priority solely by the purpose of the product or method.

An invention and utility model may not be used without a permit of the holder of the patent to another invention and another utility model with respect to which they are dependent ones.

In this case, according to the regulation, the term "another" invention or "another" utility model means the used invention or utility 
model, the patents of which belong to other patent holders. For the legal use of the dependent invention or dependent utility model, a right for exploitation must be obtained being based on the license contract for the remaining period of validity of another patent, or on a compulsory license, if there are legal grounds according to Paragraph 2 of Article 1362 of the Civil Code:

«If the patent holder cannot use the invention to which he has the exclusive right without infringing thereby the rights of the holder of another patent (the first patent) to an invention or utility model who has refused to conclude a license contract on terms corresponding to common practice, the patent holder shall have the right to initiate court action against the holder of the patent (the second patent) for the granting of a compulsory simple (nonexclusive) license for the use within the territory of the Russian Federation of the invention or utility model of the holder of the first patent. The terms of granting such a license proposed by the holder of the second patent, including the scope of use of the invention or utility model, the amount, procedure, and schedule of payments shall be indicated in the lawsuit. If this patent holder having the exclusive right to such a dependent invention proves that it is an important technical achievement and has a significant economic advantage over the invention or utility model of the holder of the first patent, the court shall rule the granting compulsory simple (non-exclusive) license. A right obtained under this license to use the invention protected by the first patent may not be transferred to other persons except in case of alienation of the second patent. A total amount of payments for such a compulsory simple (nonexclusive) license shall be determined in the decision court on the level not lower than the cost of a license determined in similar cases.

In the case of granting under the present Paragraph of a compulsory simple (non-exclusive) license, the holder of the patent for the invention or utility model, the right to use of which is granted on the basis of the aforesaid license shall also have the right to obtain a simple (non-exclusive) license for use of the dependent invention in connection with which the compulsory simple (nonexclusive) license was granted on terms corresponding to the common practice.»

Another option for the legal use of a dependent invention or dependent utility model is to acquire the exclusive right to another (first) patent by registering the exclusive right alienation agreement.

The use of a dependent patent without the consent of the patent owner of another valid patent is illegal subject to the Paragraph 1 of Article 1229 of the Civil Code of the Russian Federation and entails liability established by law. It should be considered that due to the same article of the Civil Code, «The right holder may at his own discretion permit other persons to use or prohibit them from using, the result of the intellectual activity or means of individualization. The lack of prohibition shall not be deemed consent (permission).»

Unfortunately, the current version of the Civil Code lacks a direct regulation allowing determining the dependence of one (under research) invention/utility model from another protected invention/utility model. In this case, there must be used the chain of regulations described in Paragraphs 3 and 4 of Article 1358 and Paragraph 1 of Article 1358.1, and a research carried out according to the following algorithm:

to prove the use of the studied invention/utility model in the product or method, taking into account Paragraph 3 of Article 1358 of the Civil Code of the Russian Federation (An invention shall be deemed used in a product or in a method if the product contains and the method uses each feature of the invention that had been stated in an independent item of the formula of the invention contained in the patent, or a feature equivalent thereto, and that had become known as such in the given field of technology before the invention's priority date.

A utility model shall be deemed used in a product if the product contains each feature of the utility model stated in an independent item of the formula of the utility model contained in the patent). to prove the use of another protected invention/utility model in the used invented invention/utility model, taking into account Paragraph 4 of Article 1358 of the Civil Code of the Russian Federation (If in the use of an invention or utility model all the features are also used that are stated in an independent item of the formula of another invention contained in the patent, or the feature which is equivalent thereto that had become known as such in the given field of technology before the priority date of another invention, or each feature stated in an independent point of the formula of another utility model contained in the patent another invention, another utility model shall be also deemed to be used);

to prove the impossibility of using the investigated invention/utility model in the product or method without using another protected invention/utility model;

to determine the dependence of the studied invention/utility model from another protected invention/utility model, considering Paragraph 1 of Article 1358.1 (An invention, utility model ... whose use in a product or method is impossible without using another invention, utility model ... shall be deemed a dependent invention, dependent utility model ...).

By way of example below there are excerpts from the report of judicial patent and technical expert examination of dependent and other (first) inventions [5] with regard to case \#A40-102244/15 of the Arbitration Court of Moscow. The judicial decision on the designation of a judicial expert examination raised the following questions to the expert:

Does the ECONIT device contain each feature of the invention of patent RU2446549 "Line Filter", given in an independent clause of the patent invention formula, or an equivalent feature?

Is the invention of patent RU2570351 "Line Filter" a dependent invention in relation to the invention of "Line Filter" RU2446549? If the patent holder of the invention of patent RU2570351 "Line Filter" is the manufacturer and supplier of the ECONIT device.

The studied (dependent) invention, in this case, is the invention of patent RU2570351 (priority as of 22.09.2014) with an independent primary claim in the following form:

"A line filter comprising a core inductor included in the discontinuities of each of the line wires and a core current filtering inductance provided with at least one additional winding, connected between the linear wires a capacitor and at least two filter correcting circuits, the input of each is connected to the output of one of the additional windings, characterized by additional inclusion of the bias coil and the ballast inductance with cores and control windings, threshold solver, first electronic commutating devices and second electronic commutating devices connected in-series between the linear wires."

The expert examination proved the fact of the usage of this invention in the product - the ECONIT device since this device contains each feature of the independent primary claim of the patent RU2570351. Thus, the patent holder used his invention in the product produced by himself. It may be well unless his invention was not dependent on another invention.

Another (first) invention, in this case, is the invention of the patent RU2446549 (priority as of 16.02.2011) with the following formula, characterized by an independent claim:

"A power filter comprising inductors with cores included in the rupture of linear wires and a capacitor connecting the linear wires to each other, characterized in that each of the line wires additionally includes a current filtering inductance with a core provided with at least one additional winding, and between the line wires there are included at least two filter-correcting circuits, the input of each of which is connected to the output of one of the additional windings."

The expert examination reported on the first question arose by the court: the ECONIT device contains each feature of the invention given in the independent primary claim of the invention "Line Filter" of patent RU2446549. Therefore, in accordance with the regulation of Paragraph 3 of Article 1358 of the Civil Code, this invention is recognized as used in the product ECONIT, in which the invention under study is used (patent RU2570351). 
The next stage of the study is to prove the impossibility of using the invention of the patent RU2570351 without the use of the protected invention of patent RU2446549. The proof would be the exclusion of all the features of the protected (other) invention from the formula of the studied invention. Based on the knowledge of a specialist, it can be shown that when attempting to use the remainder of the investigated invention (i.e., without the excluded features), the "reduced" invention will not achieve the technical result specified in the description, as well as will be inoperative. Therefore, the studied invention of patent RU2570351 cannot be used in a product without the use of the protected invention of RU2446549.

Thus, considering the Paragraph 1 of Article 1358.1, the studied invention of patent RU2570351 is dependent on another protected invention of RU2446549, which is the answer to the second question posed by the court for the expert.

The above-given example shows that using the dependent invention of patent RU2570351, all the features given in the independent claims of the formula of the protected (other) invention of patent RU2446549 are also used.

Therefore, another invention (RU2446549) should also be recognized as used:

it is legal if the patent holder of both patents is the same person. In case of different patent owners, it is legal if there is a permission (consent) of the patent holder of another (first) invention;

it is illegal if the patent holders are different persons having no permission (consent) of the patent holder of another (first) invention to use the dependent invention (as it was in the considered example).

Therefore, using his invention of RU2570351 in his product (ECONIT device), the manufacturer of this product violated the exclusive right of the holder of another patent RU2446549 (from which his invention is dependent) by not having obtained a consent from the prior patent holder for using the invention protected by another patent.

By the decision of the Arbitration Court of Moscow, the claims of the patent owner of another (first) patent were fully satisfied.

In conclusion, it should be noted that the regulation of Article 1358.1 of the Civil Code of the Russian Federation should be considered for noninfringement patent search at the early stages of product and technology design - at theoretical design (scientific and technical documentation), and not only at the stage of industrial production or use of technology.

\section{References}

[1]. S. Blagov. Russia amends Civil Code to introduce "significant" changes to IP protection. WIPR, 28(4), 2014, pp. 20-21.

[2]. Civil Code of the Russian Federation, 230-FZ. 2006.

[3]. Federal Law of the Russian Federation. March 12, 2014. 35-FZ "On Amending Part One, Second and Fourth of the Civil Code of the Russian Federation and Certain Legislative Acts of the Russian Federation.

[4]. E.B. Gavrilova. Strategiya patentovaniya lekarstvennykh sredstv kak instrument konkurentnoy bor'by. [The strategy of patenting medicines as an instrument of competition]. Intellektual'nye prava, 11, 2017 pp. $25-34$.

[5]. V.E. Kitaiskiy. Sudebnaya ekspertiza ob'ektov promyshlennoy sobstvennosti. [Forensic examination of industrial property objects]. Moscow: OOO RPD, 2017, pp. 195.

[6]. V.E. Kitaiskiy, V.V. Shvedova . Patentovedenie. [Patent science]. Moscow, 2014, pp. 382.

[7]. G. E. Kosinskiy. Perspektivy razvitiya zakonodatel'stva o patentakh na zavisimye izobreteniya, poleznye modeli i promyshlennye obraztsy. [Prospects for the development of legislation on patents for dependent inventions, utility models and industrial designs]. Aktual'nye problemy ekonomiki i prava $\mathrm{v}$ sfere intellektual'noy sobstvennosti. Moscow: FGBOU VO RGAIS, 2017, pp. 102-105.

[8]. S. Patrakeev, B. Malakhov. Shirokiy spektr novinok v sfere intellektual'noy sobstvennosti budet dostupen s iyulya. [A wide range of novelties in the field of intellectual property will be available from July]. Ekonomika i zhizn', 2014, pp. 12-13.
[9]. O.V. Revinskiy. Pravo promyshlennoy sobstvennosti. [The right of industrial property]. Moscow: Yurservitum, 2017, pp. 425.

[10]. T.B. Shakhmatova. Okhrana intellektual'noy sobstvennosti: novaya informatsiya i rekomendatsii. [Protection of Intellectual Property: New Information and Recommendations]. Instrumenty povysheniya izobretatel'skoy aktivnosti i razvitiya rynka intellektual'noy sobstvennosti $\mathrm{v}$ regionakh Rossii. Saransk: FIPS; RGAIS, 2014, pp. 41-42. 